\title{
Research Regarding the Influence of the Weed Control Treatments on Production and Qualitative Indicators of the Soybean Cultivated in Minimum Tillage System
}

\author{
Cornel CHET,AN ${ }^{1,2}$, Teodor RUSU ${ }^{2 *}$, Felicia, CHEȚAN $^{1,2}$,Alina ȘIMON ${ }^{1,2}$ \\ ${ }^{1}$ Agricultural Research and Development Station, Turda, 27 Agriculturii Street,401100, \\ Cluj County, Romania, Email: felice_fely@yahoo.com \\ ${ }^{2}$ University of Agricultural Sciences and Veterinary Medicine Cluj-Napoca, 3-5, \\ Manastur Street, 400372, Romania, \\ * corresponding author: rusuteodor23@yahoo.com
}

Bulletin UASVM series Agriculture 73(2)/2016

Print ISSN 1843-5246; Electronic ISSN 1843-5386

DOI 10.15835/buasvmcn-agr: 12409

\begin{abstract}
The use of herbicides abused, without a thorough knowledge can be dangerous for the environment through the introduction of toxic waste in agricultural ecosystems. It is necessary to reduce the doses used in relation to the use of conservative technology, finding solutions optimized for effective weed control. Research conducted at ARDS Turda in the years 2013 and 2014 have followed the effect of 12 variants of herbicides used to control weeds in soybean crop, sown in two tillage systems (classical system and minimal tillage system), on the soybean production and quality indicators. Tillage system significantly influenced both qualitative indices and soybean crop production (being $2635 \mathrm{~kg}$ / ha to the classical and $2131 \mathrm{~kg} /$ ha minimum tillage system). The significant influence of tillage soybeans in fat content (20.34\% in minimum tillage system; $19.94 \%$ to the classical) and on protein (39.89\% minimum tillage system; $40.56 \%$ in the classic).
\end{abstract}

Keywords: soil tillage systems, treatments, yield, quality, climatic conditions.

\section{INTRODUCTION}

Minimum tillage seeding system (MT) has evolved over time to an economic system of sustainable agriculture as an alternative to the conventional system (CS). This system improves the physical, chemical and biological soil properties, reduces the risk of environmental pollution by reducing losses of nutrients and decreased direct and indirect greenhouse gas (CO2). In that direction, minimum soil tillage systems should be applied appropriate it aimed (Fabrizzi et al., 2005; Moraru et al., 2010; Bucur et al., 2011; Rusu et al., 2014 Chețan et al., 2014; Rusu et al., 2014): reducing soil erosion and compaction, reducing energy consumption, plant protection, soil and water conservation, fuel economy. The soybean it is most valuable oleo-protein plant is grown in many countries of the world, being used all the biomass; especially are used seeds rich in protein substances, extractive un-nitrogenous, fats, vitamins and minerals salts (Muntean et al., 1995; Scurtu, 2001; Gus et al., 2004).

\section{MATERIALS AND METHODS}

The research was conducted in years 2013 and 2014, the ARDS Turda. Experimental field is located in Transylvanian Plain, on the faeoziom vertic soil type, texture clay loam, $\mathrm{pH}$ neutral, good and very good supply of phosphorus and potassium soil humus content being environment. Experience poly-factor type is organized bet on four repetitions. 
Tab. 1. The scheme of treatments

\begin{tabular}{|c|c|c|c|}
\hline Variant & Herbicide use & Rates l, g/ha & Time of aplication \\
\hline $\mathrm{C} 1$ & Martor Netratat & - & - \\
\hline $\mathrm{C} 2$ & $\begin{array}{l}\text { Dual Gold } 960 \text { EC (S-metolaclor } 960 \mathrm{~g} / \mathrm{l} \text { ) } \\
\text { Pulsar } 40 \text { (Imazamox } 40 \mathrm{~g} / \mathrm{l} \text { ) + Agil } 100 \mathrm{EC} \\
\text { (Propaquizafop } 100 \mathrm{~g} / \mathrm{l} \text { ) }\end{array}$ & $\begin{array}{c}1,5 \mathrm{l} / \mathrm{ha} \\
0,8 \mathrm{l} / \mathrm{ha}+1,5 \mathrm{l} / \mathrm{ha}\end{array}$ & $\begin{array}{c}\text { ppi } \\
\text { post I }\end{array}$ \\
\hline C3 & $\begin{array}{c}\text { Frontier Forte (Dimetenamid } 720 \mathrm{~g} / \mathrm{l}) \\
\text { Basagran Forte (Bentazon } 480 \mathrm{~g} / \mathrm{l})+ \text { Fusilade Forte } \\
\text { (Fluazifop-P-butil } 150 \mathrm{~g} / \mathrm{l} \text { ) }\end{array}$ & $\begin{array}{c}\text { 1,2 l/ha } \\
2,5 \mathrm{l} / \mathrm{ha}+1,5 \mathrm{l} / \mathrm{ha}\end{array}$ & $\begin{array}{c}\text { ppi } \\
\text { post I }\end{array}$ \\
\hline $\mathrm{C} 4$ & $\begin{array}{c}\text { Proponit } 720 \text { EC (Propisoclor } 720 \mathrm{~g} / \mathrm{l} \text { ) } \\
\text { Pulsar } 40 \text { (Imazamox } 40 \mathrm{~g} / \mathrm{l} \text { ) + Leopard 5 EC } \\
\text { (Quizalofop-P-etil 50 g/l) }\end{array}$ & $\begin{array}{c}3,0 \mathrm{l} / \mathrm{ha} \\
1,0 \mathrm{l} / \mathrm{ha}+2,0 \mathrm{l} / \mathrm{ha}\end{array}$ & $\begin{array}{c}\text { ppi } \\
\text { post I }\end{array}$ \\
\hline C5 & $\begin{array}{l}\text { Stomp } 330 \text { EC (Pendimetalin } 330 \mathrm{~g} / \mathrm{l}) \\
\text { Pulsar } 40 \text { (Imazamox } 40 \mathrm{~g} / \mathrm{l})+ \text { Select Super } \\
\text { (Cletodim } 120 \mathrm{~g} / \mathrm{l} \text { ) }\end{array}$ & $\begin{array}{c}5,0 \mathrm{l} / \mathrm{ha} \\
1,0 \mathrm{l} / \mathrm{ha}+2,0 \mathrm{l} / \mathrm{ha}\end{array}$ & $\begin{array}{c}\text { ppi } \\
\text { post I }\end{array}$ \\
\hline C6 & $\begin{array}{c}\text { Sencor } 70 \text { WG (Metribuzin } 700 \mathrm{~g} / \mathrm{kg} \text { ) } \\
\text { Basagran Forte (Bentazon } 480 \mathrm{~g} / \mathrm{l})+ \text { Agil } \\
\text { (Propaquizafop } 100 \mathrm{~g} / \mathrm{l} \text { ) }\end{array}$ & $\begin{array}{c}0,4 \mathrm{~kg} / \mathrm{ha} \\
2,5 \mathrm{l} / \mathrm{ha}+1,0 \mathrm{l} / \mathrm{ha}\end{array}$ & $\begin{array}{c}\text { ppi } \\
\text { post I }\end{array}$ \\
\hline C7 & $\begin{array}{c}\text { Guardian (Acetoclor } 820 \mathrm{~g} / \mathrm{l})+ \text { Sencor } 70 \text { WG (Metribuzin } 700 \\
\mathrm{~g} / \mathrm{kg} \text { ) } \\
\text { Pulsar } 40 \text { (Imazamox } 40 \mathrm{~g} / \mathrm{l})+ \text { Fusilade Forte } \\
\text { (Fluazifop-P-butil } 150 \mathrm{~g} / \mathrm{l} \text { ) }\end{array}$ & $\begin{array}{l}2,2 \mathrm{l} / \mathrm{ha}+0,4 \mathrm{~kg} / \mathrm{ha} \\
1,2 \mathrm{l} / \mathrm{ha}+1,5 \mathrm{l} / \mathrm{ha}\end{array}$ & $\begin{array}{l}\text { preem } \\
\text { post I }\end{array}$ \\
\hline C8 & $\begin{array}{l}\text { Dual Gold } 960 \text { EC (S-metolaclor } 960 \mathrm{~g} / \mathrm{l})+ \text { Sencor WG } \\
\text { (Metribuzin } 700 \mathrm{~g} / \mathrm{kg}) \\
\text { Basagran Forte (Bentazon } 480 \mathrm{~g} / \mathrm{l})+ \text { Leopard } 5 \mathrm{EC} \\
\text { (Quizalofop-P-etil } 50 \mathrm{~g} / \mathrm{l}) \\
\text { Basagran Forte (Bentazon } 480 \mathrm{~g} / \mathrm{l})\end{array}$ & $\begin{array}{c}1,4 \mathrm{l} / \mathrm{ha}+0,4 \mathrm{l} / \mathrm{ha} \\
1,2 \mathrm{l} / \mathrm{ha}+1,0 \mathrm{l} / \mathrm{ha} \\
1,0 \mathrm{l} / \mathrm{ha}\end{array}$ & $\begin{array}{l}\text { preem } \\
\text { post I } \\
\text { post II }\end{array}$ \\
\hline C9 & $\begin{array}{c}\text { Frontier Forte (Dimetenamid 720 g/l) + Sencor } 70 \text { WG } \\
\text { (Metribuzin } 700 \mathrm{~g} / \mathrm{kg} \text { ) } \\
\text { Pulsar } 40 \text { (Imazamox } 40 \mathrm{~g} / \mathrm{l} \text { ) + Agil (Propaquizafop } 100 \mathrm{~g} / \mathrm{l} \text { ) } \\
\text { Pulsar } 40 \text { (Imazamox } 40 \mathrm{~g} / \mathrm{l} \text { ) }\end{array}$ & $\begin{array}{c}2,5 \mathrm{l} / \mathrm{ha}+2,5 \mathrm{l} / \mathrm{ha} \\
3,0 \mathrm{l} / \mathrm{ha}+1,5 \mathrm{l} / \mathrm{ha} \\
1,0 \mathrm{l} / \mathrm{ha}\end{array}$ & $\begin{array}{l}\text { preem } \\
\text { post I } \\
\text { post II }\end{array}$ \\
\hline C10 & $\begin{array}{c}\text { Proponit } 720 \text { EC (Propisoclor } 720 \mathrm{~g} / \mathrm{l} \text { ) + Sencor } 70 \text { WG } \\
\text { (Metribuzin } 700 \mathrm{~g} / \mathrm{kg} \text { ) } \\
\text { Basagran Forte (Bentazon } 480 \mathrm{~g} / \mathrm{l})+ \text { Select Super } \\
\text { (Cletodim } 120 \mathrm{~g} / \mathrm{l} \text { ) }\end{array}$ & $\begin{array}{c}2,5 l / h a+0,4 l / h a \\
3,0 l / h a+1,5 l / h a\end{array}$ & $\begin{array}{l}\text { preem } \\
\text { post I }\end{array}$ \\
\hline C11 & $\begin{array}{c}\text { Stomp } 330 \text { EC (Pendimetalin } 330 \mathrm{~g} / \mathrm{l} \text { ) + Sencor } 70 \text { WG } \\
\text { (Metribuzin 700 g/kg) } \\
\text { Harmony } 50 \text { SG (Tifensulfuron-metil 50\%) + Agil } \\
\text { (Propaquizafop } 100 \mathrm{~g} / \mathrm{l} \text { ) } \\
\text { Harmony } 50 \text { SG (Tifensulfuron-metil 50\%) }\end{array}$ & $\begin{array}{c}4 \mathrm{l} / \mathrm{ha}+0,4 \mathrm{l} / \mathrm{ha} \\
12 \mathrm{~g} / \mathrm{ha}+1,5 \mathrm{l} / \mathrm{ha} \\
12 \mathrm{~g} / \mathrm{ha}\end{array}$ & $\begin{array}{l}\text { preem } \\
\text { post I } \\
\text { post II }\end{array}$ \\
\hline C12 & $\begin{array}{l}\text { Sencor } 70 \text { WG (Metribuzin } 700 \mathrm{~g} / \mathrm{kg} \text { ) } \\
\text { Harmony } 50 \text { SG (Tifensulfuron-metil } 50 \% \text { ) + Select } \\
\text { Super (Cletodim } 120 \mathrm{~g} / \mathrm{l} \text { ) }\end{array}$ & $\begin{array}{c}0,5 \mathrm{l} / \mathrm{ha} \\
18 \mathrm{~g} / \mathrm{ha}+2,0 \mathrm{l} / \mathrm{ha}\end{array}$ & $\begin{array}{l}\text { preem } \\
\text { post I }\end{array}$ \\
\hline
\end{tabular}

As biological material used Felix soybean cultivar (maturity group 00, during the growing season of 122 days) created the Agricultural Research and Development Station Turda.

It is a variety with high waist with a height suitable to mechanical harvesting pods insertion basal $16 \mathrm{~cm}$ and very good resistance to diseases and pests.
Experimental factors were:

A -Year 2 graduations: A1-2013; A2-2014

B-tillage system with too graduation: B1 system with conventional tillage (SC): 30 $\mathrm{cm}$ plowing rotary harrow a deep + sowing+ fertilized; B2-system minimum tillage (MT): soil processing with chisel + rotary harrow while sowing fertilization. The dose of complex mineral 
Tab. 2. Thermic regime for the years 2013, 2014 ARDS Turda

\begin{tabular}{|c|c|c|c|c|c|c|c|c|c|c|c|c|}
\hline \multirow{2}{*}{ Year } & \multicolumn{12}{|c|}{ Months - temperature recorded $\left({ }^{\circ} \mathrm{C}\right)$} \\
\hline & $\mathrm{I}$ & II & III & IV & $\mathrm{V}$ & $\mathrm{VI}$ & VII & VIII & IX & $\mathrm{X}$ & $\mathrm{XI}$ & XII \\
\hline 2013 & -2.4 & 2.0 & 3.5 & 12.3 & 16.8 & 19.4 & 20.9 & 22.1 & 13.8 & 11.2 & 7.1 & -1.7 \\
\hline 2014 & 0.5 & 3.8 & 8.8 & 11.4 & 15.1 & 18.5 & 20.4 & 19.9 & 16.6 & 10.8 & 5.7 & 1.3 \\
\hline Average 58 years & -3.5 & -0.9 & 4.1 & 9.8 & 14.7 & 17.7 & 19.6 & 19.2 & 14.9 & 9.6 & 3.8 & -1.5 \\
\hline
\end{tabular}

Tab. 3. Rainfall regime for the years 2013, 2014 ARDS Turda

\begin{tabular}{|c|c|c|c|c|c|c|c|c|c|c|c|c|}
\hline \multirow{2}{*}{ Year } & \multicolumn{12}{|c|}{ Months - rainfall recorded } \\
\hline & I & II & III & IV & V & VI & VII & VIII & IX & $\mathrm{X}$ & $\mathrm{XI}$ & XII \\
\hline 2013 & 19.8 & 10.3 & 57.9 & 53.3 & 79.3 & 86.2 & 37.6 & 44.0 & 57.8 & 67.8 & 5.9 & 3.3 \\
\hline 2014 & 51.6 & 15.5 & 23.1 & 72.0 & 66.2 & 48.4 & 144.4 & 83.8 & 48.4 & 67.4 & 34.2 & 86.8 \\
\hline Average 58 years & 21.3 & 18.6 & 23.1 & 44.7 & 67.7 & 84.5 & 76.7 & 55.9 & 40.3 & 32.0 & 32.9 & 27.8 \\
\hline
\end{tabular}

fertilizer was $100 \mathrm{~kg}$ / ha (NPK 20: 20: 0).

Sowing was done using drill Gaspardo Directa 400, John Deere tractor in aggregate, at $18 \mathrm{~cm}$ row spacing, seed depth of incorporation was $5 \mathrm{~cm}$, Rule $118 \mathrm{~kg}$ seed / ha. It provided a number of 95 grains germinate / $\mathrm{m} 2$. The size of the experimental plots is $48 \mathrm{~m}^{2}$. Previous plant soybean crop was maize.

C-12 variants herbicide graduations C1 untreated control; C2-C12: doses, combinations, and different times of application of the herbicides. The dosage schedule and application rates are summarized in Tab. 1.

Soybean harvest was performed using Wintersteiger combine experimental plots having $1.4 \mathrm{~m}$ working width. The output of each variant, in all 4 repetitions to individual weight was calculated at $12 \%$ humidity STAS then reported per hectare.

The composition of soybeans (moisture, protein, oil) was performed using infrared analyzer laboratory in Inframate Perten IM 9500.

For each sample we used a quantity of 500 grams grains obtained from the average variance on each repetition.

Pre-emergence herbicides with soil incorporation at variants 2-6 have been applied on 08.04, before seeding of soybean culture, in variants 7-12 were used herbicides applied immediately after sowing before emergence of the soybean (12.04).

Completion of pre-emergence treatments with post-emergence herbicides on vegetation was achieved when the soybean crop has 4-6 leaves, dicotyledonous weeds are in the rosette stage and perennial monocotyledonous weeds are $15-20 \mathrm{~cm}$ height ranging between hard (21.05).

Last post - emergence treatment was performed on 03.06, in versions 8.9.11, when height soy is $30 \mathrm{~cm}$ and the weeds are at a more advanced stage of growth, $22-30 \mathrm{~cm}$.

To obtain the best results we used herbicides combined with complementary action. Soybean requirements for humidity are high, critical period recorded in the second decade of June and midAugust, in stages of blooming and seed filling.

As shown in Tab. 3, for the periods indicated rainfall was lower than the average for the last 50 years which had an impact on plant growth and development, seed size and weight with a negative effect on yield.

Temperatures recorded during flowering and exploit soybean (reproductive stage) were between $19-22^{\circ} \mathrm{C}$ (Tab. 2), being the optimum range of temperature requirements to soy $\left(20-22^{\circ} \mathrm{C}\right)$.

\section{RESULTS AND DISCUSSIONS}

The degree of weeding springs dry soybean crop is higher, this is due to the adaptability of weeds to harsh environmental conditions to plant crops. Due to lack of water in the soil, so before sowing and after sowing soybean seeds had low germination, emergence faulty result, the land was invaded by weeds competed vigorously soybean plants. The rains came after a long period rather 
Tab. 4. Soybean yield in experimental years 2013, 2014 at ARDS Turda

\begin{tabular}{lcc}
\hline The factor & Yield (kg/ha) & $\%$ \\
\hline$A_{1}-2013$ & $1538^{\mathrm{Mt}}$ & 100 \\
\hline $\mathrm{A}_{2}-2014$ & $3228^{* * *}$ & 210 \\
\hline Dl (p 5\%) & 75 & \\
DL (p 1\%) & 100 & \\
DL (p 0.1\%) & 129 & \\
\hline
\end{tabular}

Tab. 5. Harvests on whichever soybean tillage, 2013-2014

\begin{tabular}{lc}
\hline Variant tillage & $\begin{array}{c}\text { Yield obtain (kg/ha) } \\
\text { and semnification }\end{array}$ \\
\hline $\begin{array}{l}\text { B }_{1} \text { - conventional with plowing system (SC): plowing +rotary harrow + sowing } \\
+ \text { fertilized }\end{array}$ & $2635^{\mathrm{Mt}}$ \\
\hline B $_{2}$ - minimum tillage system (MT): soil processing with chisel + rotary harrow + & $2131^{000}$ \\
sowing while fertilization & 121 \\
\hline DL (p 5\%) & 222 \\
DL (p 1\%) & 492 \\
DL (p 0.1\%) &
\end{tabular}

Tab. 6. Influence of herbicide treatments on soybean production, ARDS Turda 2013, 2014

\begin{tabular}{|c|c|c|c|c|c|c|}
\hline \multirow[b]{2}{*}{ The factor } & \multicolumn{3}{|c|}{ Variant comparison - C1 untreated } & \multicolumn{3}{|c|}{ Variant comparison $-\mathrm{C}_{2}$ treated } \\
\hline & Yield(kg/ha) & $\%$ & Differences & $\begin{array}{c}\text { Yield } \\
\text { (kg/ha) }\end{array}$ & $\%$ & Differences \\
\hline $\mathrm{C}_{1}$ (no treatment) & $630^{\mathrm{Mt}}$ & 100.0 & 0.00 & $630^{000}$ & 26 & -1789 \\
\hline $\mathrm{C}_{2}$ (2 treatments) & $2420^{* * *}$ & 384 & 1789 & $2420^{\mathrm{Mt}}$ & 100.0 & 0.00 \\
\hline $\mathrm{C}_{3}(2$ treatments $)$ & $1937^{* * *}$ & 307 & 1307 & $1937^{000}$ & 80 & -483 \\
\hline $\mathrm{C}_{4}(2$ treatments $)$ & $2449^{* * *}$ & 389 & 1818 & $2449^{-}$ & 101 & 29 \\
\hline $\mathrm{C}_{5}$ (2 treatments) & $2426^{* * *}$ & 385 & 1795 & $2426^{-}$ & 100 & 6 \\
\hline $\mathrm{C}_{6}(2$ treatments $)$ & $2853^{* * *}$ & 453 & 2222 & $2853^{* * *}$ & 118 & 433 \\
\hline $\mathrm{C}_{7}$ (2 treatments) & $2990^{* * *}$ & 474 & 2360 & $2990^{* * *}$ & 124 & 570 \\
\hline $\mathrm{C}_{8}$ ( 3 treatments $)$ & $3071^{* * *}$ & 487 & 2440 & $3071^{* * *}$ & 127 & 651 \\
\hline $\mathrm{C}_{9}$ ( 3 treatments $)$ & $2666^{* * *}$ & 423 & 2035 & $2666^{* *}$ & 110 & 246 \\
\hline $\mathrm{C}_{10}$ (2 treatments $)$ & $2640^{* * *}$ & 419 & 2010 & $2640^{*}$ & 109 & 220 \\
\hline $\mathrm{C}_{11}$ ( 3 treatments) & $2549^{* * *}$ & 404 & 1918 & $2549^{-}$ & 105 & 129 \\
\hline $\mathrm{C}_{12}(2$ treatments $)$ & $1964^{* * *}$ & 312 & 1334 & $1964^{000}$ & 81 & -456 \\
\hline Dl 5\% & 173 & & & 173 & & \\
\hline DL 1\% & 230 & & & 230 & & \\
\hline DL $0.1 \%$ & 299 & & & 298 & & \\
\hline
\end{tabular}

weak and quantitatively determined gradual emergence of soybean plants so that the sowing date (April 2013) to the full emergence of culture (end of May) has been almost a month, while the occupied land and weeds pre-emergence herbicides applied to soil had the desired effect. 
2014 reference year for soybean crop due to favorable climatic conditions, has led to the high yields in both systems tillage, minimum tillage and classic, which shows the applicability of minimal systems for soybean crop.

Higher values of production (2635 kg / ha) have been obtained from soybean cultivation in classical system compared to the system with minimal work, where average yields were achieved by $2131 \mathrm{~kg}$ / ha; considerable difference very negative, $504 \mathrm{~kg} / \mathrm{ha}$.

Drought in the spring of 2013 had a negative effect on soybean emergence and the effect of treatments applied to soil after sowing of resulted in yields achieved (Table 5).
Weed spectrum, time of occurrence, degree of weeding and methods of combating in differently influence soybean production. No chemical treatments (herbicides) not can control the weeds, since sowing was done at a distance of 18 $\mathrm{cm}$ between hard rows and mechanical hoeing not be done. Soybean production system dependent system tillage work and weed control, chemical and cultural methods.

The main characters of soybean by quantitative productivity (number of grains per plant, MMB, MH) are: content in fat, protein and fiber. With laboratory analyzer was performed to determine the composition of soybeans to establish relationships that exist between soil

Tab. 7. Influence of tillage system and treatments on soybean quality indices ARDS Turda 2013, 2014

\begin{tabular}{|c|c|c|c|c|c|c|c|}
\hline \multirow{2}{*}{$\begin{array}{l}\text { The factor } \\
\text { Fat } \\
(\%) \\
\end{array}$} & & \multicolumn{6}{|c|}{ Indices quality (values) } \\
\hline & & Differences & $\begin{array}{l}\text { Protein } \\
(\%)\end{array}$ & Differences & $\begin{array}{l}\text { MMB } \\
(\mathrm{g})\end{array}$ & Diferences & \\
\hline \multirow[t]{2}{*}{ A-Year } & $A_{1}-2013$ & $20.10^{\mathrm{Mt}}$ & 0.00 & $40.13^{\mathrm{Mt}}$ & 0.00 & $163^{\mathrm{Mt}}$ & 0.00 \\
\hline & $A_{2}-2014$ & $20.18^{-}$ & 0.08 & 40.32 & 0.19 & $185^{* * *}$ & 22 \\
\hline DL (p 5\%) & & 0.58 & & 0.56 & 3 & & \\
\hline DL (p 1\%) & & 2.92 & & 2.79 & 3 & & \\
\hline DL (p $0.1 \%)$ & & 29.18 & & 27.85 & 4 & & \\
\hline \multirow{2}{*}{$\begin{array}{l}\text { B-Tillage } \\
\text { system }\end{array}$} & $\begin{array}{l}\text { B1-Classic with } \\
\text { plowing }\end{array}$ & $19.94^{\mathrm{Mt}}$ & 0.00 & $40.56^{\mathrm{Mt}}$ & 0.00 & $178^{\mathrm{Mt}}$ & 0.00 \\
\hline & $\begin{array}{l}\text { B2-Minimum } \\
\text { tillage }\end{array}$ & $20.34^{*}$ & 0.40 & $39.89^{000}$ & -0.67 & $171^{00}$ & -7 \\
\hline DL (p 5\%) & & 0.18 & & 0.05 & 3 & & \\
\hline DL (p 1\%) & & 0.42 & & 0.11 & 5 & & \\
\hline DL (p $0.1 \%)$ & & 1.32 & & 0.35 & 11 & & \\
\hline \multirow{12}{*}{ C-Treatments } & $\mathrm{C}_{1}$ (no treatment) & $19.88^{\mathrm{Mt}}$ & 0.00 & $41.00^{\mathrm{Mt}}$ & 0.00 & $179^{\mathrm{Mt}}$ & 0.00 \\
\hline & $\mathrm{C}_{2}(2$ treatments $)$ & $20.13^{*}$ & 0.25 & $40.19^{000}$ & -0.81 & $174^{-}$ & -5 \\
\hline & $\mathrm{C}_{3}(2$ treatments $)$ & $20.13^{*}$ & 0.25 & $39.85^{000}$ & -1.15 & $172^{0}$ & -7 \\
\hline & $\mathrm{C}_{4}(2$ treatments $)$ & 19.86 & -0.01 & $40.43^{000}$ & -0.57 & $170^{00}$ & -9 \\
\hline & $\mathrm{C}_{5}(2$ treatments $)$ & $20.18^{* *}$ & 0.30 & $40.30^{000}$ & -0.70 & $172^{0}$ & -7 \\
\hline & $\mathrm{C}_{6}(2$ treatments $)$ & $20.00^{-}$ & 0.13 & $40.30^{000}$ & -0.70 & $179^{-}$ & 0.2 \\
\hline & $\mathrm{C}_{7}(2$ treatments $)$ & $20.31^{* * *}$ & 0.44 & $39.75^{000}$ & -1.25 & $172^{0}$ & -7 \\
\hline & $\mathrm{C}_{8}$ ( 3 treatments $)$ & $20.11^{*}$ & 0.24 & $40.28^{000}$ & -0.73 & $179^{-}$ & -0.3 \\
\hline & $\mathrm{C}_{9}$ ( 3 treatments $)$ & $20.26^{* * *}$ & 0.39 & $40.19^{000}$ & -0.81 & $169^{00}$ & -11 \\
\hline & $\mathrm{C}_{10}(2$ treatments $)$ & $20.45^{* * *}$ & 0.58 & $39.85^{000}$ & -1.15 & $175^{-}$ & -4 \\
\hline & $\mathrm{C}_{11}$ (3 treatments) & $20.29^{* * *}$ & 0.41 & $40.24^{000}$ & -0.76 & $174^{-}$ & -5 \\
\hline & $\mathrm{C}_{12}$ (2 treatments) & $20.09^{*}$ & 0.21 & $40.35^{000}$ & -0.65 & $177^{-}$ & -2 \\
\hline \multirow{2}{*}{\multicolumn{2}{|c|}{ DL (p 5\%) }} & \multicolumn{2}{|c|}{0.19} & \multicolumn{2}{|l|}{0.17} & \multicolumn{2}{|l|}{6} \\
\hline \multirow{2}{*}{\multicolumn{2}{|c|}{$\begin{array}{l}\text { DL (p 1\%) } \\
\text { DL (p } 0.1 \%)\end{array}$}} & \multicolumn{2}{|c|}{0.26} & 0.22 & & \multirow{2}{*}{\multicolumn{2}{|c|}{$\begin{array}{c}8 \\
11\end{array}$}} \\
\hline & & \multicolumn{2}{|c|}{0.34} & 0.29 & & & \\
\hline
\end{tabular}


tillage system, weed control treatments and MMB, protein and fat.

Year took that factor (climatic conditions) does not affect the content in fat and protein but very significant influence on grain weight (TKW).

Due to drought in 2013 installed, weight soybeans (MMB) had the value of 163 grams, compared to 2014, which favored the rich in rainfall cultural development throughout the growing season, resulting in high production obtained value MMB 185 grams, grains exceeding 22 grams TKW obtained in 2013.

A first criterion for assessing the quality of soybeans is protein content.

The results show that it is possible to decrease between hard limits of the content of the protein through treatment application weed control. Applying herbicides resulted not only changing protein content (very significant negative) and the fat content compared to the control (untreated).

Herbicides applied to C7-C11 variants are very significantly influenced positively in percentage fat soybeans, other variants of herbicides significantly influences and distinct significantly positive, except on $\mathrm{C} 4$ and $\mathrm{C} 6$ variants with values on $18.86 \%$ to $20.00 \%$, close to the version used as witness.

Tillage system significantly influence the content of soybeans in fat percentage values of $20.34 \%$ in minimum tillage system, being higher than the classical system, where the value is $19.94 \%$.

Tillage system contributes to changing on grain protein content, so the minimum system in protein percentage is lower (39.89) than the classical system where the value is $40.56 \%$. The minimum tillage very significant negative influence thousand grain mass, their weight is smaller than grain weight obtained from soybean cultivation in classic system with plowing (Table 7).

\section{CONCLUSIONS}

Soybean production system depends on the tillage system and weed control methods, chemical and cultural.
The year had the greatest influence on the production of soybean cultivation on two systems: classic and minimum tillage.

Treatments significantly influence distinct and highly significant positive in grains fat content but very significant negative content in protein.

Tillage system significantly positive influence of fat content in soybeans and very significantly negative content in protein.

Acknowledgments: This paper was published under the frame of European Social Fund, Human Resources Development Operational Programme 2007-2013, project no. POSDRU/159/1.5/S/132765.

\section{REFERENCES}

1. Bucur D, Jitareanu G, Ailincai C (2011). Effects of longterm soil and crop management on the yield and on the fertility of eroded soil. Journal of Food, Agriculture \& Environment Vol.9 (2): 207-209.

2. Chețan C, Rusu T, Bogdan I, Chetan F, Simon A (2014). Combaterea buruienilor la soia cultivată în sistemul minimum-tillage și producțiile obținute, la SCDA Turda. Bulletin UASVM, 71(1): 50-54.

3. Fabrizzi KP, Garcia FO, Costa JL, Picone LI (2005). Soil water dynamics, physical properties and corn and wheat responses to minimum and no-tillage systems in the southern Pampas of Argentina. Soil \& Tillage Research 81:57-69.

4. Guș P, Cernea S, Rusu T, Bogdan I (2004). Sisteme de semănat, fertilizat si întreținere a culturilor. Editura Risoprint, Cluj-Napoca.

5. Moraru PI, Rusu T, Sopterean ML (2010). Soil Tillage Conservaton and its Effect on Erosion Control, Water Management and Carbon Sequestration. In ProEnvironment, 3:359 - 366.

6. Muntean LS, Axinte M, Borcean I, Roman G (1995). Fitotehnie, EDP, București.

7. Rusu T, Chețan C, Bogdan I, Chețan F, Moraru PI, Pop AI, Duda B, Coste C (2014).Strategia de control a buruienilor din cultura de soia, Lucrari stiintifice, Universitatea Agrară de Stat din Moldova Facultatea de Agronomie, Chisinau, 41:25-30.

8. Rusu T, Chetan C, Bogdan I, Chetan F, Ignea M, Duda B, Ivan I, Bunea G (2014). Researches regarding weed control in soybean crop, Bulletin UASVM, 71(1):50-54.

9. Scurtu I (2001). Economia și tehnologia culturilor agricole. Ed. Independența economică, Pitești. 